5. Муассанит. [электронный ресурс]/статья. -электронные данные: URL:http://www.silver-lines.ru/silver/info/stone/v?id=1697384

6. Hines E., Nassau K. Cut: It's Relevance and Importance As It Pertains to a Jewel's Optical Physics. - Charles\&Colvard Created Moissanite, 2005. - 12 p.

7. Бриллиант брильянт алмаз огранка. [электронный ресурс]/статья. -электронные данные: URL:http://laser-portal.ru/content_142

8. Бриллиант брильянт алмаз огранка. [электронный ресурс]/статья. -электронные данные: URL:http://laser-portal.ru/content_142

\title{
Малоизвестное разрушительное землетрясение в Мраморном море 10.VII.1894 г.: уточнение параметров по макросейсмическим данным
}

Королева А.О., студентка,
МГРИ РГГРУ, г. Москва

E-mail: nikonov@ifz.ru

Научный руководитель:

д.2-м.н. Никонов А.A.

В пределах Средиземноморского сейсмического пояса территория северозападной Турции (провинции Фракия и Вифиния) и окрестности Босфорского пролива сейсмически малоактивны, во всяком случае, по сравнению с Малой Азией и бассейном Эгейского моря. На указанном участке землетрясения возникают редко, а сильные, если и фиксировались, то единично [1]. В этих условиях каждое сильное землетрясение представляет специальный интерес и требует особого рассмотрения. Разрушительное землетрясение 10.VII.1894 г. отражено в каталогах, однако, без указания пределов возможных отклонений, с неполным набором основных параметров, и с различиями в их значениях у разных авторов (табл. 1). Эта ситуация, а также отсутствие важных сведений в поздних сводках, побудили авторов обратиться к первоисточникам, включая и русские, и заново и комплексно обработать сведения из них с целью уточнения очаговых параметров.

Таблица 1

Основные параметры землетрясения 10. VII. 1894 по данным разных авторов

\begin{tabular}{|l|l|l|l|l|l|l|r|}
\hline Дата & Время & \multicolumn{2}{l|}{$\begin{array}{l}\text { Координаты, } \varphi^{\circ}{ }_{\mathrm{N}} ; \\
\lambda_{\mathrm{E}}^{\circ}\end{array}$} & $\mathrm{M}$ & $\mathrm{h}$, км & $\mathrm{I}_{0}$ & Источник \\
\hline 10.07 .1894 & $12: 30$ & 40.8 & 29.0 & & & $\mathrm{X}$ & {$[2]$} \\
\hline 10.07 .1894 & & 40.6 & 28.7 & 6.7 & & & {$[3]$} \\
\hline 10.07 .1894 & $18: 33$ & 40.8 & 29.1 & $(6.7)$ & $\mathrm{H}$ & $(\mathrm{IX})$ & {$[4]$} \\
\hline 10.07 .1894 & $12: 33$ & 40.6 & 28.7 & & $\mathrm{H}$ & $\mathrm{IX}$ & {$[5]$} \\
\hline 10.07 .1894 & $12: 30$ & $\begin{array}{l}40.8 \pm \\
0.1\end{array}$ & $29.0 \pm 0.2$ & $6.5 \pm 0.2$ & $\begin{array}{l}13(3- \\
25)\end{array}$ & IX \pm 0.5 & $\begin{array}{l}\text { По } \\
\text { авторам }\end{array}$ \\
\hline
\end{tabular}

В настоящем сообщении отражена только часть исследования, включающая разные группы макросейсмических проявлений, на суше и в море, вблизи эпицентра у северо-восточного побережья Мраморного моря. Значимость выявления и обработки на современном уровне надежных первичных сведений о разрушительном землетрясении 
в непосредственной близости к такому городу, как Стамбул, и к проливу международного мореплавания Босфор не требует объяснений.

Событие, как оказалось, имеет особенности, важные как в региональном плане, так и для познания сейсмического процесса как такового. Основной фактический материал почерпнут из публикации Директора Геофизической обсерватории в Афинах Д. Эгенитеса [6], который сам обследовал потрясенную область и собирал сведения от местных жителей, а также из забытой публикации очевидца из России [7]. Учтены также оценки интенсивности в нескольких дополнительных пунктах из каталога землетрясений Турции [2].

Основные сведения вкратце собраны в таблицу 2.

Таблица 2

Основные сведения по главным пунктам

\begin{tabular}{|c|c|}
\hline Пункты, I0 & Основные характеристики \\
\hline $\begin{array}{c}\text { Макри-кюи, } \\
\text { VIII-IX }\end{array}$ & Непосредственно перед землетрясением вода стала теплее, чем \\
всегда.
\end{tabular}

По собранным пунктам с максимальными сотрясениями VIII-IX и VIII баллов (в шкале MSK-64), всего 10 пунктов, стало возможным очертить изосейсту VIII-IX баллов. Она отчётливо отражает вытянутость эпицентральной области в направлении 3СЗ-ВЮВ, с размерами осей, длинной 94 км и короткой 22 км. Общая площадь области сотрясений VIII-IX баллов составляет $S=2$ тыс. км ${ }^{2}$, площадь, оконтуренная изосейстой VIII баллов может быть принята около 3 тыс. км². За эпицентр взят не геометрический центр высшей изосейсты VIII-IX баллов, а пункт поблизости, в акватории у двух западных из трех Принцевых островов, на которых возникли одинаково ориентированные трещины на поверхности земли. Поскольку они простирались параллельно вытянутости длинной оси высшей изосейсты, они могут быть связаны с очаговым разрывом. Намеченная позиция эпицентра подкрепляется также распространением возникающих обычно в областях с сотрясениями $\geq$ VIII-IX баллов, аномалий в виде тепловых отклонений и водных фонтанов, как это обнаружилось при нанесении сведений о таковых на крупномасштабную карту с пунктами интенсивности сотрясений. Простирание эпицентральной области в нашем варианте оказалось сходным с определявшимся Д. Эгенитесом [6], но с уточнениями, - в направлении ЗС3$300^{\circ}$, (рис.).

За главным толчком последовал рой афтершоков. Возможно, и само событие включало несколько сильных толчков друг за другом, с распространением их 
эпицентров к запад-северо-западу. Сильный толчок последовал на следующий день после главного [7], а вся серия продолжилась до конца сентября 1894 [8].

В пределах эпицентральной области обращает внимание наличие целого ряда признаков, показательных, как в отношении интенсивности колебаний в отдельных пунктах и в самом г. Стамбул, так и важных для понимания особенностей и кинематики развития процесса в очаге (табл. 2).

Для определения глубины очага землетрясения, которая прежде, если и оценивалась, то только как нормальная (н) (см. табл. 1), мы использовали номограммы в издании [9]. Определения произведены, во-первых, по размеру и площади, охваченной изосейстой VIII баллов (приближённо), и, во-вторых, по расстояниям, $\Delta$, (км) $\mathrm{I}_{0}-\mathrm{I}_{\mathrm{i}}$ для 10 пунктов с определениями интенсивности в приэпицентральной области, а также в 12 пунктах с I = VII, VI, V, III баллов. Операции осуществлялись в двух вариантах - при принятии коэффициентов затухания $v=3.0$ и $v=3.5$. Глубина очага определялась с использованием номограмм в [9] по двум макросейсмическим показателям - по площади, оконтуренной высшей изосейстой, и по расстояниям от эпицентра до пунктов с имевшимися определениями интенсивности (от VIII до III баллов).

Получив средние значения глубины очага и возможные пределы неточностей, авторы, используя номограммы в базовом издании [9], определили значение магнитуды независимо от прежних оценок. И в этом случае определения сделаны в вариантах принятия коэффициента затухания $v=3.0$ и $v=3.5$. Полученные значения $\mathrm{M}=6.4$ и $\mathrm{M}=6.6$ близки между собой и к приводившимся ранее с незначительным понижением (см. табл. 1).

Помимо сведений о поведении водной среды в нескольких пунктах важным является сообщение об изменении уровня моря, в пункте Сан-Стефано вблизи города Стамбул после и, без сомнения, в результате землетрясения [6]. Указание на последовательность изменения - сначала море отступило от берега, а затем набросилось на берег с яростью - позволяет видеть в нем цунами. Значимость такого, даже краткого, указания возрастает при соединении со сведениями Н.И. Андрусова об изменении глубин в прилежащей части акватории Мраморного моря [8]. Этот вопрос, как и вопросы сейсмотектоники, является предметом дальнейшей проработки авторами.

Полученные в результате нового подхода, на расширенной базе фактических данных, оценки параметров события приведены в заключительной строке таблицы (табл. 1). Основные результаты исследования землетрясения 10.VII.1894 г. заключаются в следующем. По новым определениям, с использованием нескольких групп макросейсмических признаков (в 22 пунктах) интенсивность события определена $\mathrm{I}_{0}=\mathrm{IX} \quad( \pm 0.5)$ баллов, глубина очага $\mathrm{h}=13 \quad( \pm 10 \quad$ км$)$, магнитуда $\mathrm{M}_{\mathrm{s}}=6.5 \pm 0.2$. Землетрясение произошло в ближайших окрестностях г. Стамбул, его эпицентр находился в Мраморном море в 15 км к юго-востоку от города. Эпицентральная область оказалась вытянутой в направлении 3С3-300, площадь внутри изосейсты VIIIIX баллов составила S=2 тыс. км². Оно стало сильнейшим в окрестностях города за последние несколько столетий. В пределах эпицентральной области выявлен ряд предвестниковых явлений, сопровождавших и последовавших нарушений в природной среде, как на суше, так и в море. Важно, что за землетрясением последовало цунами, причем вода в море сначала отошла от берега, а затем набросилась на него. 
Полученные определения позволяют уточнить существующие оценки сейсмической опасности мегаполиса.

Авторы благодарны К.И. Никоновой за перевод с французского и Л.Д. Флейфель за помощь в подборе литературы.

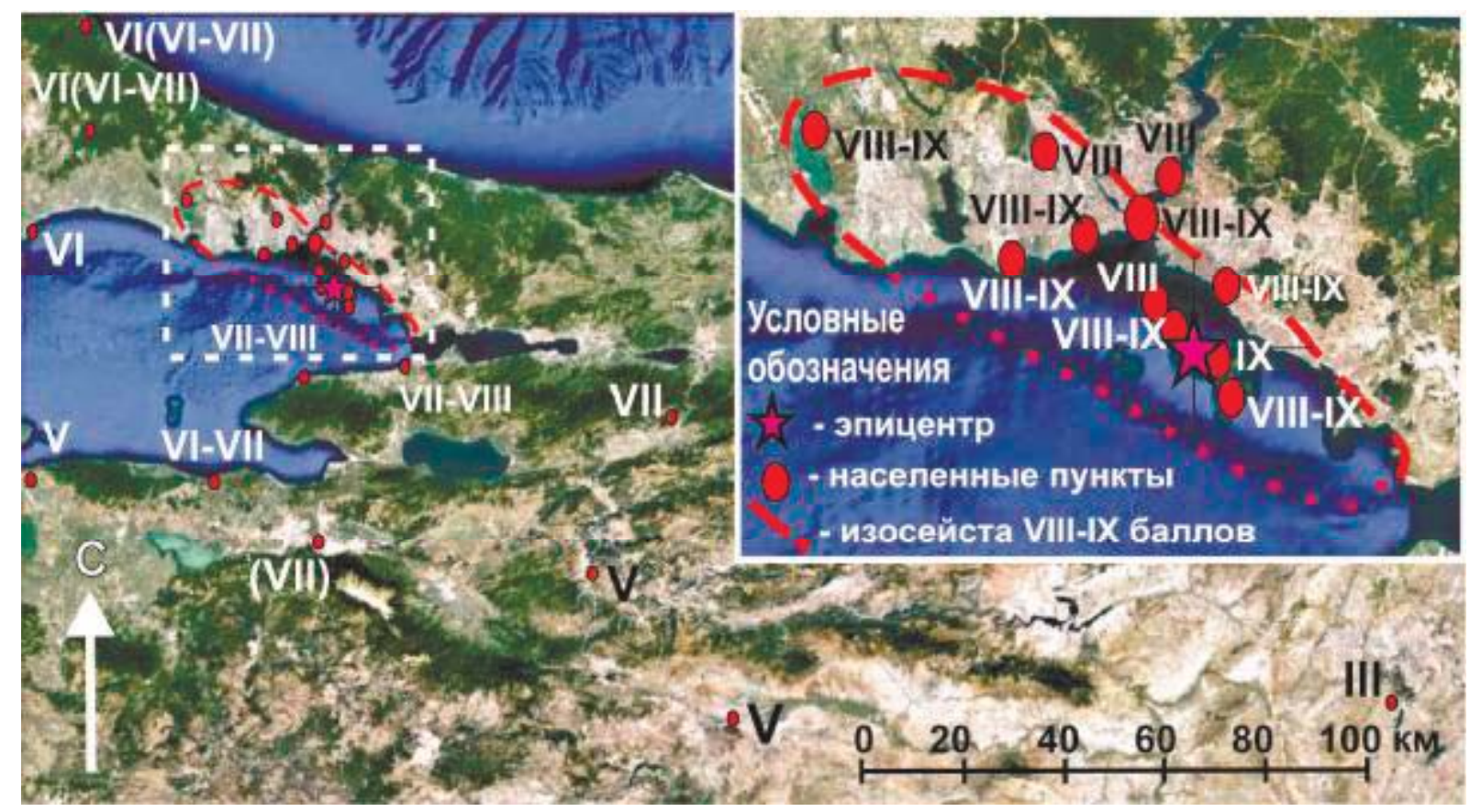

Рис. 1. Карта идентифицированных пунктов макросейсмических проявлений землетрясения 10. VII. 1894 года. На врезке показана приэпицентральная область

\section{Список литературы:}

1. Полякова Т.П. Сейсмичность центральной части Средиземноморского пояса. М.: Наука, 1985. 160 с.

2. Soysal H., Sipahioglu S., Kolcak D., Altinik Y. Turkiye ve çevresinin tarihsel deprem kataloğu. İstanbul, 1981. 124 p.

3. Papadopoulos G. A., Chalkis B. J. Tsunamis observed in Greece and the surrounding area from Antiquity up to the present times. 1984. Pp. 309-317.

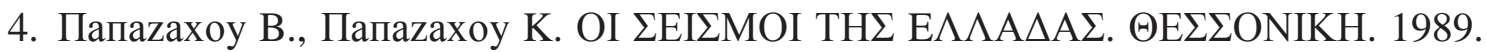
$356 \mathrm{p}$.

5. Karnik V. Seismicity of Europe and the Mediterranean. Praha, 1996.

6. Eginites D. Le tremblement de terre de Constantinople du 10 juillet 1894 // Annales de Geographie publiees par Yidal de la Blache 1895. № 15. Pp. 151-165.

7. Амфитеатров А. В. Землетрясение в Стамбуле 1894 г. СПб.: Товарищество «Общественная польза», 1904.

8. Андрусов Н.И. Экспедиция «Селяника» на Мраморное море // Записки Имп. Русск. Географ. общ-ва. 1896. С. 15-19.

9. Новый каталог сильных землетрясений на территории СССР с древнейших времен до 1975 г. М.: Наука, 1977. 536 с. 